\title{
First Report of Tomato Spotted Wilt Virus Identified in Tulbaghia violacea in Florida
}

\author{
K. K. Dey, ${ }^{\dagger}$ C. Li, M. C. Sellers, John McVay, L. Whilby, G. Hodges, and T. R. Smith \\ Florida Department of Agriculture and Consumer Services, Division of Plant Industry, Gainesville, FL 32614
}

Accepted for publication 26 May 2019.

Keywords: vectors, virology, ornamentals, society garlic, thrips

Tulbaghia violacea Harv., commonly known as society garlic, is an herbaceous perennial bulbous plant belonging to the genus Tulbaghia (Amaryllidaceae). It is diversely used for medicinal, culinary, and ornamental purposes. The plant owes its characteristic odor and perhaps its reported medicinal properties to its richness in sulfur-containing compounds (Aremu and Van Staden 2013; Kubec et al. 2002). Studies have verified that extracts of different plant parts of $T$. violacea exhibit antibacterial, antifungal, anticancer, antioxidant, and anthelmintic activities (Ncube et al. 2011). In June 2018, T. violacea plants from Lake County, FL, with typical tospovirus-like symptoms of chlorotic ring patterns (Fig. 1) were submitted to the Florida Department of Agriculture and Consumer Services, Division of Plant Industry (Gainesville, FL) for identification. Representative leaf tissue from four plants tested positive in serological testing with commercially available tomato spotted wilt virus (TSWV) lateral flow immunoassay reagents (Agdia, Elkhart, IN) and/or broad-spectrum tospovirus enzyme-linked immunosorbent assay (ELISA) reagents (Bioreba, Reinach, Switzerland). To further confirm identification, two samples of symptomatic $T$. violacea were further analyzed by reverse transcription-polymerase chain reaction (RT-PCR). Total RNA was extracted from representative samples using an RNeasy Plant Mini Kit (Qiagen, Valencia, CA) and was used as a template in RT-PCR with primers specific for the nucleocapsid (N) gene of TSWV (Koehler et al. 2016). Samples were also tested for iris yellow spot virus (IYSV) using primers IYSV-465c and IYSV-239f (Pappu et al. 2008). Amplicons of the expected size, $780 \mathrm{bp}$, were produced using the TSWV $\mathrm{N}$ gene primers but not using IYSV primers. Amplicons of $\mathrm{N}$ gene from a representative sample were directly sequenced and deposited in GenBank (MK567883). The 777-bp N gene sequence had 98 to 99\% nucleotide identity with the corresponding region of previously described Georgia TSWV isolates (KU179517.1, KU179597.1, and HQ406914.1) and 96 to $99 \%$ nucleotide identity with all TSWV isolates in GenBank.

Epidemics of TSWV occur frequently in numerous crops in Florida, chiefly tomato, pepper, tobacco, and ornamentals (Pappu et al. 2009). The western flower thrip, Frankliniella occidentalis (Pergande), is the most efficient vector of TSWV (Wijkamp et al. 1995) and has become established in Florida. This is the first report of TSWV infection in T. violacea. Additional surveys and evaluation will be needed to understand the potential impact of this virus on this plant.

${ }^{\dagger}$ Corresponding author: K. K. Dey; E-mail: kishore.dey@freshfromflorida.com

Funding: This work was funded by Florida Department of Agriculture and Consumer Services.

The author(s) declare no conflict of interest.

(C) 2019 The American Phytopathological Society

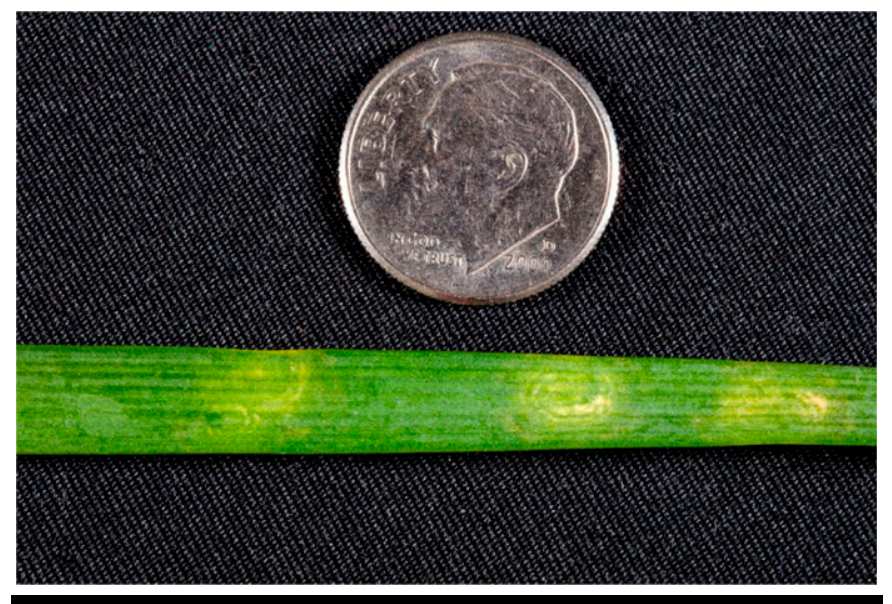

FIGURE 1

Symptomatic leaves of Tulbaghia violacea exhibiting chlorotic rings.

\section{Acknowledgments}

The authors thank Department of Plant Industry (DPI), Florida Department of Agriculture and Consumer Services (FDACS) for all assistance with the project.

\section{Literature Cited}

Aremu, A. O., and Van Staden, J. 2013. The genus Tulbaghia (Alliaceae)-A review of its ethnobotany, pharmacology, phytochemistry and conservation needs. J. Ethnopharmacol. 149:387-400.

Koehler, A. M., Brown, J. A., Huber, B., Wehner, T. C., and Shew, H. D. 2016. First report of Tomato spotted wilt virus in Stevia rebaudiana in North Carolina. Plant Dis. 100:1251.

Kubec, R., Velíšek, J., and Musah, R. A. 2002. The amino acid precursors and odor formation in society garlic (Tulbaghia violacea Harv.). Phytochemistry 60:21-25.

Ncube, B., Ngunge, V. N. P., Finnie, J. F., and Van Staden, J. 2011. A comparative study of the antimicrobial and phytochemical properties between outdoor grown and micropropagated Tulbaghia violacea Harv. plants. J. Ethnopharmacol. 134:775-780.

Pappu, H. R., Jones, R. A. C., and Jain, R. K. 2009. Global status of tospovirus epidemics in diverse cropping systems: Successes achieved and challenges ahead. Virus Res. 141:219-236.

Pappu, H. R., Rosales, I. M., and Druffel, K. L. 2008. Serological and molecular assays for rapid and sensitive detection of Iris yellow spot virus infection of bulb and seed onion crops. Plant Dis. 92:588-594.

Wijkamp, I., Almarza, N., Goldbach, R., and Peters, D. 1995. Distinct levels of specificity in thrips transmission of tospoviruses. Phytopathology 85 : 1069-1074. 